Volume 21

Issue 2 Winter 1972: Symposium on

International Human Rights / Student

Article 5

Symposium on Prosecutorial Abuse

\title{
The Inter-American Human Rights System
}

Fernando Fournier

Follow this and additional works at: https://via.library.depaul.edu/law-review

\section{Recommended Citation}

Fernando Fournier, The Inter-American Human Rights System, 21 DePaul L. Rev. 376 (1972)

Available at: https://via.library.depaul.edu/law-review/vol21/iss2/5

This Article is brought to you for free and open access by the College of Law at Digital Commons@DePaul. It has been accepted for inclusion in DePaul Law Review by an authorized editor of Digital Commons@DePaul. For more information, please contact digitalservices@depaul.edu. 


\title{
THE INTER-AMERICAN HUMAN \\ RIGHTS SYSTEM
}

\author{
FERNANDO FOURNIER*
}

\section{HISTORICAL BACKGROUND}

$\Pi$ WO EVENTS, both dating back to the 18 th century, are of historic importance in establishing the rights of the individual.

1 The first is the proclamation of the Declaration of the Rights of Man and the Citizen, which occurred in the first stages of the French Revolution. ${ }^{1}$ The second is the adoption of the first ten amendments to the Constitution of the United States, ${ }^{2}$ which enumerated a list of basic rights. Since then, many new constitutions have specifically provided guarantees to the personal liberties of the individual.

On March 19,1812, the Spanish people, abandoned by their king in midst of the struggle against Napoleon, promulgated a liberal constitution for the monarchy, commonly known as the "Cadiz Constitution,"3 which specifically acknowledged the political rights of men. It should be remembered that the present Spanish American republics were just then beginning their wars of independence, and delegates of the Spanish colonies of the American continent were still present in the "Cortes" (Parliament) which adopted that constitution. It was therefore only natural for different Spanish American republics to be influenced by the new developments in the constitutional field. Thus, one of those countries' first gestures of sovereignty was to create a constitution, a legal text that stated the basic lines which the new political organization was to follow, and the main features that the state was to adopt.

* Mr. Fournier is an attorney at law, partner of Facio, Fournier, \& Canas, San Jose, Costa Rica.

1. 5 Aachette, Historre Universelle (Universal History) $352-54$ (Paris 1920).

2. Wambaugh, A Selection of Cases on Constitutional Law XXII-XXVII (1915); A. Mason and W. Beaney, American Constitutional Law 437 et seq. (4th ed. 1968).

3. Artola, 1 Los Origenes de la España Contemporânea (Orignns of CONTEMPORARY SPAIN) 459 (Madrid 1959). 
Copying from the pattern established by the French and North American texts of 1789 and the Spanish text of 1812, the very first constitutions in Latin America included a list of the basic human rights which the respective founding fathers of each of those republics considered essential for the happiness of their people. Typical examples were the project for a constitution presented by Simon Bolivar on May, 1826 to the new Republic of Bolivia, ${ }^{4}$ and the Federal Constitution for the United Provinces of Central America adopted in Guatemala City on November 22, $1824 .^{5}$ The inclusion of a bill of rights as one of the main foundations on which those nations were built should be considered a uniform characteristic of the constitutional law of the Latin American nations since their formation as independent republics.

Contrary to the North American experience, however, all of the Latin American republics had more than one constitution during their independent lives; indeed some have had as many as ten or twelve. Their agitated political history has made it necessary that whenever a revolution or coup d'etat takes place, the countries must adopt new constitutions either to reestablish the constitutional order or to legalize the forced change of government. In addition, the restricted scope of court interpretation has made it difficult to adapt the law to meet the needs of changing times. As a result substitution or amendment has been indispensable, because they are often the only available recourse which would accommodate the fundamental law to new problems. Federal regimes have been transformed into unitary ones; the president's term in power has varied widely; bicameral systerms have become unicameral, etc. However, despite these changes, it is interesting to see that the chapter dealing with human rights has been present in all the constitutions of Latin America.

Even more significant is the fact that the section on human rights contained in various constitutions has increasingly had a more detailed and elaborated wording, reflecting a constant effort to prevent loopholes and manifesting a growing desire to make such provisions more effective. For example, when the Constitution of El Salvador

4. Fombona, El Pensamiento Vivo de Bolivar (Bolivar's Thinking) 121 (Buenos Aires 1942).

5. Peralta, las Constituciones de Costa Rica (Costa Rican ConstituTrons) $133-146$ (San Jose 1962). 
was approved on February 1, 1841, article 82 of the Constitution declared with respect to the freedom of movement that, "any citizen or inhabitant, free of responsibility may emigrate whenever he pleases and return whenever he may wish." Salvador, enacted on January 8, 1962 elaborates and makes more explicit the same kind of freedom in article 54:

Any person is free to enter or to remain in the territory of the Republic and to leave it, excepting the limitations that the Law may establish. Nobody may be forced to change his domicile or residence excepting by judicial authority, in special cases and according to the requirements that the Law may indicate.

No Salvadorean may be expatriated nor be denied the right to enter the territory of the Republic, or be denied of a passport to return or other documents of indentification.7

To be sure, the tendency to adopt more detailed constitutional texts is not limited solely to the area of human rights but is a general trend within all Latin American constitutions. For that reason both the extension of their texts and the number of their articles have increased considerably. The first Constitution of Costa Rica of December $1,1821^{8}$ for instance, has only 58 articles; the present one, promulgated on November $8,1949,{ }^{9}$ has 197 articles.

This inclination to write progressively more detailed constitutions is also due to the fact that constitutional law in Latin America has gradually enlarged the scope and number of the subjects to be covered by its provisions. Many of these subjects have only slight relation to the topic of human rights, while other subjects have a more direct relation thereto.

The development of the legal rules related to the electoral rights of the citizen is an example of the expanded scope of constitutional law. The possibility of freely choosing a government is undoubtedly one of the fundamental liberties of men. For that reason, some Latin American states, during the present century, have tried persistently

6. Menéndez, Recopilación de las Leyes del Salvador en Centro America (Recompilation of the Laws of El Salvador in Central America) 32 (Imprenta Nacional ed. San Salvador 1966).

7. Zeledón, Digesto Constitucional Centroamericano (Central american Constitutional Digest) 126 (San Jose 1962).

8. Zeledón, Digesto Constitucional de Costa Rica (Constitutional Digest of Costa Rica) 9-14 (San Jose 1946).

9. 3 Asamblea Nacional Constituyente de 1949 (The National ConSTITUENT ASSEMbly of 1949) 647-85 (San Jose 1953). 
to surround it with the best possible guarantees, thus attempting to ensure a healthy functioning of a democratic regime, and a respect for all other human rights.

The most advanced and complete legislation in Latin America concerning elections are the laws of Uruguay ${ }^{10}$ and Costa Rica ${ }^{11}$ Coincident to the development of their electoral legislation has been the improvement of the practical application of those laws. The basic guarantees of electoral rights have received constitutional status, with secondary laws implementing the necessary details, creating a system which secures a free and accurate manifestation of the will of the people in the selection of a new government. The whole election process is delegated to an independent court, whose members are appointed without political intervention. The court has complete autonomy in determining all electoral matters, including the verification of election returns. In Costa Rica, the court enjoys the exclusive right to interpret the constitution regarding electoral matters and to issue orders for the police, who are the only armed force in the country. Data concerning Costa Rican citizens is compiled in an official registry which includes photos and fingerprints. The Costa Ricans are free from coercion and enjoy total secrecy when casting their vote. Political propaganda is regulated and a high percentage of the electoral campaign expenses are shared by the state in order to maintain a basic economic equilibrium among the respective parties.

In the years following the Uruguayan and Costa Rican adoption of electoral provisions, other republics of the hemisphere enacted laws which, in one way or another, have followed similar patterns. ${ }^{12}$

10. Uruguay Const. art. 68 (as amended in 1942); see A. Peaslee, ConSTITUTIONS OF NATIONS 397-98 (1950).

11. Costa Rica Const. arts. 90-104 (1949); see Ley Organica del Tribunal Supreme de Elecciones y del Registro Civil (Fundamental LaW of the Supreme Electoral Tribunal and the Civil Registry) (Imprenta Nacional San Jose 1969; Codigo Electoral (Electoral Code) included in same publication.

12. See as examples of that trend: Ley Electoral Federal (Electoral Federal Law) [Mexico 1955 published by Secretaria de Gobernacion (Department of the Interior)]; Ley General Sobre Inscripoines Electorales (General Law on Electoral Registration) and Ley de Elecciones (Law on Elections) (Chile 1958 published by the Civil Registry and Identification Service); Estatuto ElecTORal (Electoral Rules) (Venezuela 1951 published by the Ministry of Internal Relations, Imprenta Nacional). 


\section{DEVELOPMENT OF SOCIAL AND ECONOMIC RIGHTS}

Another field in which the scope of human rights has been extensively enlarged is that of social and economic justice. Achievements in this field are reflected by the impact of economic and social justice upon the judicial branches of government in Latin America.

Today it is widely accepted, as stated by the International Commission of Jurists, that

[t]he Rule of Law requires the establishment and observance of certain standards that recognize and foster not only the political rights of the individual but also his economic, social and cultural security. It is endangered by the continued existence of hunger, poverty and unemployment, which tend to make a truly representative form of government impossible and promote the emergence of systems of government opposed to the principles of the Rule of Law.13

This attitude has significantly influenced the judicial systems in Latin American countries. Before the end of the first half of the twentieth century, each country had adopted necessary legislation (reflected in entire new chapters in their constitutions, numerous laws, and governmental institutions and regulations) in an attempt to realize the above mentioned aims. In 1910 Alfredo L. Blacios, ${ }^{14}$ an Argentine law professor, published a book which quickly fomented a movement which had significant influence on positive law. The first constitution affected by this movement, thereby witnessing a recognition of social rights, was adopted by Mexico on January 13, 1917, commonly known as the "Queretaro Constitution."15 This important innovation is a special triumph of the Constituent Congress. President Carranza, in addressing the assembly in its inaugural session, announced his purpose of giving the future congress of the country the power to formulate laws in labor matters, hoping in such a way to begin to establish institutions that would favor the working class. It has been explained:

The drafting Commission did not reject those points from the project; but doubted that it could become a part of the section on individual rights. Thus, even though the Commission finally went beyond the original Carranza's project, it resisted the idea of mingling guarantees for special groups of men with the chapter related to the rights of men as individuals, probably due to the influence of the traditional constitutional theory then still in vogue.

13. The Rule of Law and Human Rights-Principles and Definitions, INTERNATIONAL COMmission OF Human Rights, 44 (Geneva 1968).

14. A. Palacios, El Nuevo Derecho (The New Law) (Buenos Airles 1927).

15. 2 PeAsleE, supra note 10 , at 415 to 459 . 
On January 23, 1917 finally a favorable report of the Commission was tabled for discussion, including even the right for labor strikes. At last 163 congressmen approved it by unanimity and also they approved Article 5 and that to be in the future Article 123 to be entitled "About Labor and Social Welfare."

... I believe it is enough to state that the declaration on social rights contained in the Mexican Constitution was at that time the best acknowledgement for the rights of the workers, becoming a model to be followed by many other legislations of the World. 10

Other countries proceeded to follow the trend: the Cuban Constitution of July $5,1940,{ }^{17}$ the 1943 amendment ${ }^{18}$ to the Costa Rican Constitution of 1871 , and finally most of the constitutions of Latin Republics. ${ }^{19}$ The first labor code of the hemisphere was enacted by Chile in $1931 ;^{20}$ now practically all the Latin American republics have a similar code along with such related institutions as social security, workman's compensation, labor courts, etc.

In order to destroy the absolutism of previous times . . . the individual was elevated and enthroned as a god, supposing him to have a perfect reason, believing all of them were uniformly the same, with identical rights and duties and free of any relationship born out of their existence within a society.

Individual rights were then looked upon as mere barriers against public power and the activities of the latter only distrustfully accepted.

But nowadays it is better understood the role to be expected on part of public power, instead of thinking of it as a mere judge or only a policeman to watch the peaceful coexistence of men; ..... (The public power) everyday is requested to take care of more collective problems which force it to intervene in new sectors of society in regard to different aspects of human life ... and now we should talk not only about human rights but of individual duties as well.

That trend is reflected in the most recent Latin American constitutional texts; the Constitution of Venezuela of 1961 gives us an example by merely reading the names of its corresponding chapters: "Duties of the Individual," "Rights of the Individual," "Social Rights," "Economic Rights" and "Political Rights".21

16. 3 Derechos del Pueblo Mexicano. Mexico a-traves de sus Constituciònes (Rights of tHe Mexican People. Mexico Under its Constitutions) 606-10 (published by the Mexican Congress 1967).

17. History Academy of Cuba, Constiruciones de la Republica de Cuba (CONSTItUtions of tHe Republic of CUBA) 195-241 (Artes Graficas 1952).

18. 1 PeAslee, supra note 10 , at 501 .

19. See 1 and 2 Clausulas Economico Sociales en las Constituciones de America (Socio-Economic Clauses IN THe Constitutions of America) (Buenos Aires 1948).

20. D. antokoletz, Tratado de la legislación del Trabaje y Prevision Social (Treatise on Labor and Social Welfare Legislation) 114 (Buenos Aires 1941). For the complete text of the Chilean Code see official edition by the Chilean Government, 1957.

21. A. Bascunan, Tratado de Derecho Constitution (Treatise on ConSTitutional LAW) 436-39 (Santiago 1963). 


\section{IMPLEMENTATION OF HUMAN RIGHTS}

\section{IN LATIN AMERICA}

If an opinion on the status of human rights was based solely on the aforementioned legal collections, it might be concluded that human rights are satisfactorily and duly protected throughout Central and South America. Surely, those countries have some of the most complete and modern laws on the subject of human rights, laws to which any nation of any other part of the world might aspire.

However, is the ideal translated into an actual observation of those rights? Are all of those theoretical safeguards really enforced in practice? It is very doubtful indeed. With perhaps the exceptions of Chile, Uruguay, and Costa Rica, where civil liberties and the functions of a democratic system have only had one or two eclipses throughout their independent history, the cruel fact is that human rights are not respected or truly protected in many sections of Latin America. In some instances this situation has been in effect for decades. Civil freedom and basic rights of the human being have been systematically neglected in many of the Latin republics, notwithstanding provisions appearing in legal text.

A well-known Argentine law professor states it very clearly: ${ }^{22}$

Another characteristic of institutional practices in Latin America is the great importance given to the necessity of keeping a picture or image of constitutionality, at the same time that the strict performance of the constitutional principles is unjustifiably forgotten. The frequent lack of political preparation of the masses also contributes to all the aforementioned problems, because civic education and culture on the part of the people are the pillars which should sustain any republican system of government. ${ }^{23}$

22. 1 S. Linares Quintana, Tratado de la Ciencia del Derecho Constitucional (Treatise on Constitutional Law Science) 84-85 (Buenos Aires 1953).

23. Id. at 84-85; For deeper examination and more detailed analysis of the problem see, among others: Bulletin OF THE INTERNational Commission of JuRISTs No. 28 at 36 (Geneva December 1966); id. No. 4 at 5 (Geneva December 1969); M. RICART, FUNCION DE LAS INSTITUCIONES EN LA INSTAURACION Y MANTENIMIENTO DE LA DEMOCRACIA (FunCtION OF INSTITUTIONS IN THE INSTAURATION and Maintenance of Democracy) 323 (Caracas 1961); E. Ravines, America Latina un Continente en ERupcion (Latin America a Continent in ERuption) 231 et seq. (1956); Several articles which have appeared at Combate a review specially published bimonthly by Instituto Internacional de Estudios Politicos-Sociales (Intemational Institute of Socio-Political Science) (San Jose, Costa Rica) Volumes 1, 2, 7, and 10. Several articles appeared in Panoramas a review published bimonthly by Centro de Estudios y Documentacion Sociales (Center of Social Studies and Documentation) (Mexico City) especially Volumes 3, 5 and 6. Of great interest in this regard is also to examine the pronouncements of the 
For example, although the Trujillo regime (1930-1961) subjected the Dominican Republic to one of the most sordid and arbitrary dictatorships of modern times, that nation always possessed a constitutional chapter on human rights. ${ }^{24}$ Hence, it was possible to state in a report by officials of that government and published by the United Nations in 1959 that:

The principle enunciated by Article 9 of the Universal Declaration of Human Rights, according to which nobody may arbitrarily be arrested, detained or exiled, has been in all times respected at the Dominican Republic, where it is consecrated not only by the Constitution, but by the law and jurisprudence as well.

The constitutional and legal principles related to individual security are applied very strictly by judicial authorities; the interested government bodies show always the best vigilance so that said principles should not lose their value in any way and all contribute to the protections. ${ }^{25}$

Moreover, the report further mentions article 8 of the Dominican Constitution, which lists (at great length) guarantees for the personal freedom of the citizen in addition to several complementary laws which quite nicely regulate habeas corpus, arrest of criminals, publicity of trials and independence of the courts, among others. ${ }^{26}$

Another recent example in point is the Venezuelan dictatorship of Perez Jimenez (1948-1958) which had little regard for individual liberties. ${ }^{27}$ Nevertheless, the laws of the country were framed in the classical formality, proclaiming human dignity and democracy.

To be sure, few dictatorships have gone to the extremes of the Trujillo or Perez Jimenez regimes; however, it is evident that only a small number of Latin American nations have entirely escaped ex-

Roman Catholic Church, mainly those adopted by the Bishops Conference held in Medellin, Colombia, September, 1968; see Documentos De Medellin. II CoNferencia General del Episcopado latinoamericano (Medellin, DocumentsII General Conference of the Latin American Episcopate (San Jose 1969).

24. YEARBOOK ON HUMAN RIGHTS FOR 1955, 47-52 (United Nations 1957).

25. Droit en Vertu Duquel Nul ne Peut etre Arbitrairement ArRete, Detenu ou Exile (LaW by Which Nobody May Be Arbitrarily Arrested, DeTAINED OR EXILED) 96-101 (Supplement published by Economic and Social Council of the United Nations 1959).

26. Bulletin of THE INTERNATIONAL Commission of JuRists No. 17 at 15 (Geneva December 1963) and id. No. 11 at 61 (Geneva December 1960).

27. For a more detailed account of common violation of human rights perpetrated at that time in Venezuela, see Restablecimiento DeL REgIMEN JuRIDICo (REestablishment of a JURIDICAL ORder) [Supplement for the Revista del Ministerio de Justicia (Ministry of Justice Review) Caracas]; R. BETancourT (former President), Venezuela: Politica y Petroleo (Venezuela: Politics and PetroLEUM) (Mexico 1956). 
periences of a similar extreme as the divorce between the excellent wording of legal texts dealing with human rights and reality.

Faced with the need of global change of the Latin American structures, we feel that such an aim requires political reform. The political authority and its decisions should have the common good as its only task. In Latin America such authority and decisions frequently appear as favoring systems that go against such common good or favor privileged groups. Governments should efficiently and permanently assure, through juridical norms, the rights and liberties which are inalienable to the citizens and the free functioning of intermediate structures. Governments should propitiate and strengthen the creation of mechanisms for the participation and legitimate representation of the people. 28

The problem is that human rights guarantees-as well as all other juridical norms-cannot live in a vacuum nor be imposed by fiat. They should result from and be sustained by many other social factors and circumstances. The best laws of the world will not be enforced if public opinion does not exert a permanent vigilance to that end. Without a widely spread popular education such public opinion may not function, thereby rendering the right to freely choose the men to govern a country a mere farce. In the absense of such a milieu, the military and the small cliques have assumed the power to rule. An independent judiciary is ineffective when the legal provisions creating and sustaining human rights are never applied and never transformed into social reality.

If serious economic differences also prevail in a society, the tragic picture of a vicious circle is completed; excellent proclamations of social justice and other legal measures never go beyond the books in which they are printed, rarely touching upon large sectors of the population. Resultantly, the failure of governments to solve the difficult and acute social and economic problems often precipitates the exchange of human liberties for dictators offering solutions.

Human rights regulations do not become effective at conception. They become a reality only through a delicate equilibrium of social, economic, cultural, and political factors. Human rights may not function unless a complete system of balances and counterbalances guarantees impartial enforcement of the law.

... The States are the ones which, in the first place, should adopt the necessary measure for the individual rights to have a true effectiveness in the domestic field. That is what is normal; the States by their own means, adopt those measures, and

28. The Medellin Documents of the Catholic Church, supra note 23. 
in case of a violation of the rights to be acknowledged, they should offer jurisdictional recourses to obtain an adequate remedy. 29

As Professor Andre Tunc of the University of Grenoble, France, has also aptly said:

Government under law. The law should not govern only relationships between individuals. It should govern also the government itself. ... Only then may the individual be content with the law. Only then may he be content with the State. . . A principle is nothing . . . unless it is enforced.30

Written principles become more than mere words when a country develops political and social balances that allow the existence of certain brakes applicable to the government, which thus becomes a government governed by the law-to use Professor Tunc's phrase. A legal system may then develop guarantees for the effective application of human rights, and only then will habeas corpus, judicial review of the unconstitutionality of laws, the writ of "amparo,"31 the Contentious-Administrative action, ${ }^{32}$ and similar recourses now established in some Latin American countries become truly functional. ${ }^{33}$ Only when such recourses or similar ones effectively exist may we talk about a real existence of a rule of law, and expect to obtain a satisfactory situation for the development of human rights.

In regard to the internal implementation of human rights in the Latin American countries, it is of interest to examine the manner in which Puerto Rico has tried to protect individual liberties. As a Spanish speaking country closely tied politically to the United States during the last seventy years, it has been strongly influenced by United States Public Law and, undoubtedly, through measures mainly

29. E. Sayagues Laso, Los Derechos Humanos y las Medidas de Ejecucion (Human Rights and Measures of Enforceability) 110 (La Habana 1953).

30. Lecture given at Harvard Law School on occasion of the Bi-centennial of John Marshall, September 22-24, 1955 [published by Harvard in Government UNDER LAW 35 (1956)].

31. Literally means "protection," a sort of habeas corpus applicable to the defense of individual liberties other than personal freedom, as this last one is usually specifically and separately protected by habeas corpus.

32. A judicial action which allows citizens to sue the government to obtain a regular court to declare void an act of the administration in Civil Law countries without previous permission.

33. For further explanation of how some of those typical Latin American judicial recourses function as exemplified in the Republic of Costa Rica, see an abstract of Harvard lecture, supra note 30: COMMENTs-Fernando FourniER, Government under Law 83-86 (1956). See also Statements of the Laws of Costa RICA, Pan American Union (Washington 1969) for an explanation of "amparo" (p. 283) and "Contentious-Administrative Jurisdiction" (p. 292). 
reflecting the Anglo-Saxon pattern, individual rights are generally safeguarded domestically. ${ }^{34}$

\section{INTERNATIONAL IMPLEMENTATION OF HUMAN RIGHTS}

Unfortunately, conditions prevailing in many of the Latin American countries have hindered development of an atmosphere in which governments as well as the citizens can be truly subject to the law. In some, even if a system of law has existed, its survival has been a precarious one, because it is only partially or weakly enforced. Since the development of a strong domestic guarantee for the respect of human rights has been generally lacking, many have looked to international achievements in the belief that these mechanisms may offset national factors.

The use of the international doctrine of asylum reflects this belief. Established by international conventions in the middle of the nineteenth century, ${ }^{35}$ asylum is still a viable concept in Central and South America. It operates on the principle that when local conditions do not avail the citizens of the security granted by local legal texts, political enemies of the regime in power may validly obtain sanctuary by seeking refuge in an embassy, legation, or the territory of another country. Surprisingly, the practice is generally respected even by governments which otherwise feel no inhibitions or limitations in the persecution of its own nationals.

In addition to asylum, the recognition of governments has also been considered as a possible wedge by which international control over the legality of governmental regimes and the preservation of human rights in Latin America could be instituted. The idea was first advanced in the early years of the twentieth century by Tovar, Foreign Minister of Ecuador, as a means to prevent legally elected governments from being overturned by revolutions and coups d'etat. The desideratum was to deny recognition of regimes arising from violent changes in government. The so called "Tovar Doctrine" received

34. In regard to this subject, it is very valuable to consult: INFORMEDEL Comite del Gobernador para el Estudio de los Derechos Civiles en Puerto Rico (Report of the Governor's Committee for the Study of Human Rights in Puerto Rico) (1959).

35. The last Conventions adopted and still force those suscribed in the: $\mathbf{X}$ INTER-AMERICAN CONFERENCE IN CARACAS (1954). 
formal recognition in article I of the Additional Convention to the Treaty of Washington, signed by the five Central American republics in 1907, and repeated in the Treaty of 1923 subscribed to by the same nations. The thesis has also been applied in diplomatic policy by several American governments at different times during the present century. ${ }^{36}$ Nonetheless, the principle has never been enacted as a collective rule of International Law for the Americas.

As it is presently applied, however, the non-recognition of governments doctrine has not proved to be an effective measure in the preservation of human rights for three basic reasons. First, the ephemeral nature of non-recognition produces slight impact on delinquent governments which bide their time. Second, it has sometimes been used as an instrument of foreign intervention. Third, and most importantly, the validity of a government sometimes has little to do with human rights. In other words, whether or not a government is the result of a revolution should not be the criterion to determine if it merits condemnation by the society of nations as a violator of human liberties.

... general principles (to regulate the recognition of governments) should be flexible enough, in a way as to allow the recognition of de facto Governments which are instrumental to the establishment of a democratic system and to allow to deny such recognition to de facto governments, and even those with a legal facade, which may violate the essential rights of men or deny the essence of representative democracy. .. . To discriminate only as to the peaceful or violent origin of new governments, does not resolve the problem of the existence of anti-democratic governments in our Continent, nor helps in most cases to eliminate them. ${ }^{\mathbf{3 7}}$

For all the reasons previously examined, if recognition of governments is ever to abet the enforceability of human rights in Latin America, the actual recognition should be reserved until a rational judgment is collectively exerted, founded on a government's true respect for human rights, not by simply resting upon formal compliance with purely external legal appearances.

36. For a more complete examination of the subject, see e.g. E. Barros, Manual de Derecho Internacional Publico (International Law Handbook) 165-71 (Santiago 1955); A. Verdross, Derecho International Publico 219-20 (Madrid 1957); J. Sanson Teran, Doctrinas y Principios Americanes de Derecho Internacional (American Doctrines and Principles of International Law) 91-117 (Managua, Nicaragua 1963).

37. Facio, Rectificacion de la Politica Costarricense sobre no reconocimiento de Gobiernos de Facto (Amendment to the Costa Rican Policy of Non-recognition of de facto governments), 22 Costa RiCAN Bar Association ReVIew 10-11 (1967). 


\section{DIRECT INTERNATIONAL CONTROL OF HUMAN RIGHTS}

Still another possibility available at the international level is a mechanism through which the community of nations may deal directly (not indirectly as is the case with asylum and the non-recognition of governments) with human rights problems. In other words, the establishment of a regional judicial system founded upon the European model, which has for 10 years openly disciplined and judged those member countries which have violated the fundamental principles of human dignity.

The initial experience in regional judicial systems can probably be dated back to the early twentieth century. The treaty ${ }^{38}$ signed by Guatemala, Honduras, El Salvador, Nicaragua, and Costa Rica in 1907 in the City of Washington, at the invitation of the Governments of Mexico and the United States, established the first permanent international court of justice. The Court's main purpose was "to guarantee with its authority ... the rights of each one (of the member states) in their reciprocal relations, as well as to maintain them in peace and harmony;"39 thus, it was a tribunal fundamentally designed to arbitrate differences between the constituting states. However, Article II of the Convention granted to that Court the probable right:

to adjudicate also matters to be presented by citizens of a Central American country against any contractual government due to violation of treaties or conventions and any other cases of international matter, whether supported by his Government or not; and as long as any recourses given by the laws of the respective country have been exhausted or a denial of justice is demonstrated.40

Five cases based on Article II were actually received by the Court during its ten years of existence. Of these only one ${ }^{41}$ was processed with procedural defenses:

The basic failure in this kind of cases is to be found in the requirements of the Convention ... that the complaints should exhaust the recourses granted by the

38. The complete text of the General Treaty is contained in Coleccion DE Leyes de Costa Rica (Costa Rican Laws Series) 80-89 (San Jose 1908), and also the Convention creating the Court id.92-103.

39. ARTICle 1 OF THE INTERNal Regulations of the COURT (Library of the Court-Foreign Affairs Ministry of Costa Rica).

40. Article II of the Convention, supra note 38.

41. Alejandro Bermudez v. Republica de Costa Rica, 4 Anales de la Corte de Justicia Centroamericana (Central American Court of Justice Annals) 30 (1914). In this case, plaintiff, a Nicaraguan citizen, had been expelled from Costa Rica for violating the neutrality of the latter country during a revolution in Nicaragua. 
laws of the respective country or to demonstrate a denial of justice. Such demonstration came to be impossible to comply with and, the Justices themselves in their proposed reforms (to the Convention) suggested to substitute it with the simple evidence that a writ of habeas corpus had been denied." 42 "On the other hand, as Justice Madriz and Corea point out, according to this Article (the II) it was not possible to sue about a case of injustice made by a Government against a citizen of its own country, as still that was considered as a purely domestic issue. . . .43

The Convention which created the Court had a term of ten years expiring in 1917, which was not renewed. This was due to the difficulties between Nicaragua and the United States arising under a treaty which was condemned by the Court as a violation of the former of her international obligations. ${ }^{44}$ As a result, Nicaragua refused to continue participating in the functioning of the Court. ${ }^{45}$ While political rivalries between the participant states provoked the eventual demise of the Court, it should be remembered that another reason for the Court's failure evolved as a result of its inherent nature. The fact cannot be overlooked that the Court was designed to cope with problems (human rights problems and otherwise) of only a very few community of republics, in which political clashes were always more virulent and more difficult to dilute by mere transfer to a society of nations.

No other manisfestation of international concern toward new movements in Latin America became evident until after World War II. At that point several general declarations were made, reassuring that democracy and human rights were part of a fundamental creed of the American republics and one of the cornerstones of the Inter-American community: Declaration XI of the Cjapultepec Conference of $1945 ;^{46}$ Preamble to the Inter-American Treaty of Reciprocal Assis-

42. C. Gutiérrez, La Corte de Justicia Centroamericana (The Central American Court of Justice) 59 (San Jose 1957).

43. Id. at 16.

44. Republic of Costa Rica v. Republic of Nicaragua, 6 Anales de la Corte de Justicia Centroamericana (Central American Court of Justice Annals) 110 (1916); Republic of El Salvador v. Republic of Nicaragua, 7 Anales de la Corte de Justicia Centroamericana (Central American Court of Justice Annals) 56 (1917).

45. C. Gutierrez, supra note 42, at 58-60; see also M. Castro Ramirez, Cinco Anos en la Corte de Justicia Centroamericana (Five Years in the Centrai American Court of Justice) (San Jose 1918); H. Lopez Villamil, La Corte Centroamericana de Justicia en la Politica International (The Central American Court of Justice in International Politics) (Madrid 1960).

46. Declaration XI of the Cjapultepec Conference of 1945: "The American man does not believe in living without justice. He does not believe in living without liberty either." See art. 12 Final Act-Official Publication of Mexican GovERNMENT (Translated from Spanish). 
tance signed in Rio de Janeiro in $1947 ;^{47}$ Introduction to the Charter of the Organization of American States signed in Bogota in April, 1948:48 Article 13 of Chapter III, entitled "Fundamental Rights and Duties of States" of the same Charter, ${ }^{49}$ The American Declaration of the Rights and Duties of Man of the same Charter adopted at the IX International American Conference held in Bogota in April, $1948^{50}$ and The Declaration of Santiago, signed at the Fifth Meeting of Foreign Affairs Ministers held in 1959 in Santiago, Chile. ${ }^{51}$

Despite a reluctance in the past on the part of some to recognize the area of human rights, most are now willing to concede that human rights may/can be internationally defined. But as Dr. Enrique Sayagues Laso of Uruguay astutely indicates:

[t]he controversy arises, however, when the point comes to determine who has competition to put into practice, and to make applicable, those rights so defined by international norms - which is the positive aspect of the problem - and whether international bodies may have intervention in controlling how those rights are abided by in the internal field of each country - which is the negative aspect of the question-....

47. ". . . that peace is founded on justice and moral order and therefore on the recognition and international protection of the rights and liberties of the human being, on the indispensable well-being of people and the effectiveness of democracy. ...." Inter-American Treaty of Reciprocal Assistance signed in Rio de Janeiro (1947) preamble, Final Act, Official Publication of the Brazilian Government (Translated from Portugese).

48. "Believing that the genuine sense of American solidarity and good neighborhood may not be other than the consolidation in this Continent, within the framework of democratic institutions, of a regime of individual liberty and social justice founded on the essential rights of men . . . CHARTER of THE ORganizaTion of American States signed in Bogota, April, 1948, introduction, Final Act, Official Publication of the Columbian Government (Translated from Spanish).

49. "The State shall respect the rights of the human being and the principles of universal morals." Charter of THE Organlzation of AMERICAN STATES signed in Bogota, April 1948 art. 13 ch. III (1948), Final Act, Official Publication of THE Colombian Government (Translated from Spanish).

50. The American Declaration of the Rights and Duties of Man, CHARTER OF the Organization of American States signed in Bogota, April, 1948, art. 13 ch. III (1948), Final Act, Official Publication of the Colombian Government (Translated from Spanish).

51. "Harmony among the American republics may be effective only as long as the respect for human rights and fundamental liberties and the practice of representative democracy are a reality within the internal scope of each one of them. The existence of anti-democratic regimes constitutes a violation of the principles on which the Organization of American States is founded." The Declaration of Santiago signed at the Fifth Meeting of Foreign Affairs Ministers, Santiago, Chile (1959): Final Act, Official Document of the Pan American Union Ser. C/II.5 at 4 (English). 
It may occur that nowithstanding there are jurisdictional procedures (within each country), the damage persists, that the rights acknowledged by international norms are not fully satisfied. That will take place whenever there are domestic legal provisions which contradict international rules. . . .

Some other times, as it was the case in totalitarian countries, judges supposedly bound to make justice, are inspired by the same political thinking of government and then do not dare or don't want to bridle government excesses. . . .

It may also happen that [internal] jurisdictional recourses do exist, but function so ineffectively, that in fact there is a true violation of human rights. 52

This reasoning expresses the reluctance of people and states to accept theoretical declarations or definitions of the fundamental rights which should be granted to human beings. With this as background, it becomes necessary to digress to the efforts of the Court, although rudimentary and ineffective. The theoretical concept may be effective in the creation of international mechanisms to supplement deficiencies of domestic recourses. If the population of a country is not adequately educated or does not possess the basic political freedoms needed to make domestic legal procedures effective, only international bodies may give to that people the substance necessary to reestablish the social equilibrium, and thereby obtain respect for their basic rights.

On the other hand, it is a mistake to believe that such international guarantees for civil rights involve a violation of popular sovereignty or the non-intervention principle.

States, when taking obligations such as a Human Rights treaty, even though they accept a restriction to their jurisdiction or competence, they are only making use of an attribute of their sovereignty, which instead of being hampered, it is reaffirmed by such an act.

If states, exercising their sovereignty, freely accept certain norms of conduct, through an international instrument duly ratified, for the protection of human rights in their respective jurisdiction and to create international bodies empowered to watch the observance of such norms ... that undoubtedly does not embody an illegitimate act of intervention. ... .

... the Convention, instead of clashing with sovereignty has as its aim to protect it and to prevent its perversion, since sovereignty belongs to the people and the nation; the international guarantee of human rights brings precisely a protection to the sovereign for the free expression of its will, initial foundation of the law and of any legitimate authority.

Moreover .... it opens a judicial channel for the solution of those reactions provoked by the violation of human rights ... and eliminates one of the principle reasons which congest the continental political atmosphere . . .

52. E. SAYAGUES, supra note 29 , at $96,110$. 
Thus, a Convention like that ... instead of damaging a national sovereignty or the principle of non-intervention, it will be a guaranty for their observation. 53

\section{THE SAN JOSE CONVENTION ON HUMAN RIGHTS}

Not until 1959, at the 5th Meeting of Foreign Affairs Ministers held in Santiago, Chile, did the Inter-American governments ${ }^{54}$ resume the task of creating international mechanisms, intended to supervise the effective application of human rights. By Resolution VIII,, the Inter-American Council of Jurists was directed to make a draft of a Convention on Human Rights.

In Part II of the same Resolution VIII, an explicit decision was made to create an Inter-American Commission on Human Rights, destined to "promote respect for said rights" and organized by the Council of the Organization of American States. Implementing that decision by a Resolution of May 25, 1960, the Council of the Organization of American States established the Commission and enacted a set of regulations to rule its functions and activities. ${ }^{56}$ For the first time in the hemisphere, a body existed with legal capacity to take measures of execution. The Commission was, however, limited: ${ }^{57}$ (a) to act as a conscience for human rights; (b) to formulate recommendations; (c) to prepare studies or reports; (d) to ask the governments to submit information about measures taken on matters related to human rights; and (e) to serve as consultative body of the Organization of American States on human rights.

At the same time, the Inter-American Council of Jurists, following Resolution VIII, had already prepared a first draft for a Con-

53. Resolution adopted at the Symposium about the Project of Convention on Human Rights formulated in Santiago de Chile, held in Montevideo, Uruguay on October, 1959 at 23 (Symposium published by the Library of Official Publications of the Law School and Social Sciences of the University of the Republic $\S$ III, CVIII Montevideo 1959).

54. Fifth Meeting of Foreign Affairs Ministers, Santiago, Chile (1959): Final Act, Official Document of the Pan American Union Ser. C/II.5 (English).

55. Fifth Meeting of Foreign Affairs Ministers, Santiago, Chile (1959) Res. VIII: Final Act, Official Document of the Pan American Union Ser. C/II.5 10-12 (English).

56. Inter-American Commission on Human Rights-Basic Documents: OfFicial Document of the Pan American Union Ser. L/V/L 4 Rev. 9-14 (Portuguese) (Oct. 15, 1963).

57. Inter-American Commission on Human Rights art. 9: OfFicial Document of the Pan American Union Ser. L/V/L 4 Rev. 9-14 (Portuguese) (Oct. 15, 1963). 
vention on Human Rights which was adopted at the meeting of that Council held in Santiago from August 24 to September 9, 1959. ${ }^{68}$ The project also included the creation of a Court for the Protection of Human Rights. ${ }^{59}$ The final Convention was adopted and presented for ratification after an interim of ten years. The delay was caused by the postponement of the International American Conference for undefined political reasons.

In the meantime, the Commission on Human Rights was integrated, organized, and began to function by performing a significant role in defending human rights throughout the hemisphere, notwithstanding the limited facilities with which it was empowered. However, the Inter-American system was still lacking a binding international instrument which clearly rendered human rights a legal obligation, imposed on the States and protected by a judicial organ with enforcement powers. Other drafts which proposed convention functions were prepared by the governments of Chile and Uruguay, but these were subject to long delays ${ }^{60}$ before any action was begun.

At an extraordinary Inter-American Conference held in Rio de Janeiro in November, 1965 (Resolution XXIV), impetus was finally given to the project formulated in Santiago, as well as the Chilean and Uruguayan projects. It was decided that the Santiago project should be revised by the Council of the Organization of American States, together with Chilean and Uruguayan propositions, and that these revisions should be sent to all American Governments for comments. Later, all revisions and comments would be compiled and set forth in a conference for the purpose of adopting a definite Treaty on the subject. ${ }^{61}$

In order to implement that Resolution, the Secretariat of the Commission on Human Rights prepared: (a) an analysis of the 1959 draft of Santiago; ${ }^{62}$ (b) a comparative study of the original project

58. Inter-American Council of Jurists: OfFicial Document of THE PAN AMERICAN UNION SER. E/XI/1, Doc. 8 (1959).

59. Inter-American Council of Jurists: OfFicial Document of The PaN AMERICAN UNION SER. E/XI/1, Doc. 8, 28-34 (1959).

60. See Second Special Inter-American Conference: Documents 35 AND 49 [Topic V Sept. 30 and Nov. 18, 1965 (English)].

61. Inter-American Conference in Rio de Janeiro (November 1965): FinaL Act, Official Document of the Pan American Union Ser. C/I/IE.

62. Parecer elaborado por la Comision Interamericana de Derechos Humanos sobre el Projecto de la Convencion de Derechos Humanos aprobado por el Consejo 
of 1959, the United Nations International Covenants on Human Rights, and the amendments that the Commission itself was proposing to the original Inter-American project; ${ }^{63}$ and (c) a comparative study of the original $1959 \mathrm{draft}$ and the Chilean and Uruguayan projects. ${ }^{64}$

Based on the above documents, the Council of the Organization of American States on October 2, 1968, adopted a working paper to be submitted to the governments, and afterwards sent the working paper and the observations of those governments to the Specialized Conference on Human Rights, which Resolution XXIV of the Second Extraordinary Inter-American Conference of Rio de Janeiro had called for since $1965 .{ }^{.55}$ The conference took place on November 7, 1969, in San Jose, Costa Rica, with the participation of a great majority of American States. The San Jose Conference was able to adopt on November 22, 1969, a Convention with only two reservations (actual signers were the delegates of Argentina, Brasil, Colombia, Costa Rica, Chile, Ecuador, El Salvador, the United States, Guatemala, Honduras, Mexico, Nicaragua, Panama, Paraguay, Peru, Dominican Republic, Uruguay, Venezuela, Trinidad and Tobago; there were also observers present from several European countries and international organizations).$^{6 \theta}$ While the requisite number of ratifications may not be available immediately, it is hoped that the convention will be effective in the near future.

The instrument adopted has many excellent features making it an

de Jurisconcultos (Opinion of the Inter-American Commission of Human Rights about the draft made by the IACJ): OfFicial Document of THE Pan AMERICAN UNION Ser. L/V/II/15 Doc. 26 \& SER. L/8/11 Doc. 16 (Espanol).

63. Comparative Study of the International Covenants on Human Rights adopted by the United Nations (December, 1966), the draft convention on Human Rights of the Inter-American Council of Jurists and the text of the Amendments to the IACJ draft adopted by the Inter-American Commission on Human Rights: OFFIcial Document of Pan American Union Ser. L/V/II. 19 Doc. 4 (English) (May 22, 1968).

64. See Comparative Study of the Draft Convention on Human Rights prepared by the Inter-American Council of Jurists and those presented by Uruguay and Chile to the Second Special Inter-American Conference: PAN AMERICAN UNION SER. L/V/II/15 Doc. 2 (English) (June 22, 1966).

65. Council of the Organization of American States (October 2, 1968): OFFIcial Document of Pan American Union Ser. G/V/ Doc. C-D 1631 (English) (October 2, 1968).

66. Organization of American States Inter-American Specialized Conference on Human Rights: Doc. 65 ENglish Rev. 1 (November 22, 1969). 
effective vehicle for the preservation of human rights. It also demonstrates a definite improvement over the drafts composed prior to its adoption. The first part of the Treaty contains a complete list which defines those rights to be protected. The second part, however, is the more important, since it delineates the means of protection to effectuate the Convention. This latter section not only maintains the InterAmerican Commission, but also creates an Inter-American Commission of Human Rights.

The Commission has the following principal functions: ${ }^{67}$ (a) to make recommendations to the governments to adopt measures in favor of human rights; (b) to request reports from the governments; and (c) to act upon complaints of violations of the Convention. Such complaints can be brought by individuals and nongovernmental entities under Article 44. Unfortunately, state complaints are accepted only through an optional clause established by Article 45 . On the other hand, however, Article 46 definitely recognizes the possibility that human rights may be violated in spite of the existence of apparent guarantees written into the law of a country; thus, in spite of these "in writing" guarantees if that fact is demonstrated, the complaint may still be processed. Upon the presentation of the complaint and a corroboration of the facts by the Commission, an opinion will be issued and correcting recommendations made. ${ }^{68}$

The Court consists of seven judges elected in an individual or personal capacity. ${ }^{69}$ Only states and the Commission may submit cases to it; the Commission should have examined the case before the Court may act upon it. ${ }^{70}$ However, it is regrettable that the jurisdiction of the Court on any related case is made only by way of an optional clause. ${ }^{71}$ The Court is allowed by Article 63 to take provisional measures for the immediate protection of a person threatened

67. Organization of American States Inter-American Specialized Conference on Human Rights art. 41: Doc. 65 ENGLISH Rev. 1 (November 22, 1969).

68. Organization of American States Inter-American Specialized Conference on Human Rights art. 51: Doc. 65 ENGLISH ReV. 1 (November 22, 1969).

69. Organization of American States Inter-American Specialized Conference on Human Rights art. 52: Doc. 65 ENGLish Rev. 1 (November 22, 1969).

70. Organization of American States Inter-American Specialized Conference on Human Rights art. 61: Doc. 65 ENGLISH Rev. 1 (November 22, 1969).

71. Organization of American States Inter-American Specialized Conference on Human Rights art. 62: Doc. 65 ENGLISH Rev. 1 (November 22, 1969). 
in his rights. Judgments are final ${ }^{72}$ and binding on all state parties and if compensatory damages are granted, they may be executed in accordance with the domestic procedure regarding the execution of judgments. ${ }^{73}$

The perennial problem of enforcement exists with respect to the possible condemnation of a government's acts where there is no compliance. The problem obviously goes beyond a purely legal field. In a very practical manner, however, Article 65 of the Convention acknowledges that fact and attempts to give a political solution to the problem: if the Court is confronted with such a case, it should report it to the next General Assembly of the Organization of American States, where the case may be dealt with and decided upon a political basis.

The Convention, as envisioned, will bring to the respective countries a considerable improvement in the methods for implementation of human rights within their territories. Without this type of international mechanism, one will not see the widespread observation of human rights throughout Latin America. The general enforcement of its present provisions, and the eventual future correction of the weaknesses included in the final text may furnish those countries with the previously lacking international leverage required to disrupt the aforementioned vicious circle, which at this point has made impractical the obtention of a permanent application of the basic rights of the human being.

72. Organization of American States Inter-American Specialized Conference on Human Rights art. 67: Doc. 65 ENGLish Rev. 1 (November 22, 1969).

73. Organization of American States Inter-American Specialized Conference on Human Rights art. 68: Doc. 65 ENGLISH Rev. 1 (November 22, 1969). 